\title{
Revisited and Revised: Is RhoA Always a Villain in Cardiac Pathophysiology?
}

\author{
Shigeki Miyamoto • Dominic P. Del Re • \\ Sunny Y. Xiang • Xia Zhao • Geir Florholmen • \\ Joan Heller Brown
}

Received: 26 March 2010 / Accepted: 22 April 2010 / Published online: 27 May 2010

(C) The Author(s) 2010. This article is published with open access at Springerlink.com

\begin{abstract}
The neonatal rat ventricular myocyte model of hypertrophy has provided tremendous insight with regard to signaling pathways regulating cardiac growth and gene expression. Many mediators thus discovered have been successfully extrapolated to the in vivo setting, as assessed using genetically engineered mice and physiological interventions. Studies in neonatal rat ventricular myocytes demonstrated a role for the small G-protein RhoA and its downstream effector kinase, Rho-associated coiled-coil containing protein kinase (ROCK), in agonist-mediated hypertrophy. Transgenic expression of RhoA in the heart does not phenocopy this response, however, nor does genetic deletion of ROCK prevent hypertrophy. Pharmacologic inhibition of ROCK has effects most consistent with roles for RhoA signaling in the development of heart failure or responses to ischemic damage. Whether signals elicited downstream of RhoA promote cell death or survival and are deleterious or salutary is, however, context and cell-type dependent. The concepts discussed above are reviewed, and the hypothesis that RhoA might protect cardiomyocytes from ischemia and other insults is presented. Novel RhoA targets including phospholipid regulated and regulating enzymes (Akt, PI kinases, phospholipase C, protein kinases $\mathrm{C}$ and $\mathrm{D}$ ) and serum response element-mediated transcriptional responses are considered as possible pathways through which RhoA could affect cardiomyocyte survival.
\end{abstract}

Shigeki Miyamoto and Dominic P. Del Re contributed equally

S. Miyamoto $\cdot$ D. P. Del Re $\cdot$ S. Y. Xiang $\cdot$ X. Zhao $\cdot$

G. Florholmen $\cdot$ J. H. Brown $(\square)$

Department of Pharmacology, University of California,

9500 Gilman Dr., La Jolla,

San Diego, CA 92093-0636, USA

e-mail: jhbrown@ucsd.edu
Keywords RhoA - Cardiomyocyte Ischemia $\cdot$ ROCK

\section{$G \alpha_{q}$ and RhoA Signaling Pathways in Cardiac Hypertrophy}

There is considerable evidence that G-protein coupled receptors (GPCRs) that interact with the heterotrimeric Gprotein, $G \alpha_{q}$, mediate cardiac hypertrophy (see Fig. 1). In neonatal rat ventricular myocytes (NRVMs), GPCR agonists such as norepinephrine (NE), phenylephrine (PE), and endothelin 1 (ET-1), acting through $\alpha_{1}$-adrenergic and ET-1 receptors coupled to $\mathrm{G} \alpha_{\mathrm{q}}$, induce cardiac hypertrophy as evidenced by fetal gene expression, myofilament organization, increased protein synthesis, and cardiomyocyte enlargement [1-7]. In vivo studies subsequently demonstrated that transgenic expression of $\mathrm{G} \alpha_{\mathrm{q}}$ induces hypertrophy, as does $\mathrm{G} \alpha_{\mathrm{q}}$ expression in NRVMs [8-10]. Development of hypertrophy in mice subjected to transverse aortic constriction (TAC) was subsequently shown to be prevented by transgenic expression of a peptide inhibitor that blocks GPCR coupling to $\mathrm{G} \alpha_{\mathrm{q}}$ [11], or by genetic deletion of the alpha $(\alpha)$ subunit of $\mathrm{G} \alpha_{\mathrm{q}}$ and its homolog $\mathrm{G} \alpha_{11}$ [12]. The best known effector of $\mathrm{G} \alpha_{\mathrm{q}}$ is phospholipase C (PLC) [13, 14], and accordingly, signals generated through phosphoinositide hydrolysis, including activation of protein kinase $\mathrm{C}$ (PKC) and of $\mathrm{Ca}^{2+}$-regulated enzymes such as calcineurin and CaMKII have been considered to serve as downstream mediators of GPCR effects on hypertrophic gene expression and cell enlargement $[15,16]$.

Studies carried out in vitro and subsequently in vivo also suggested that a low-molecular-weight G-protein, RhoA, plays a role in development of cardiac hypertrophy. Early studies from our group and others showed that in the NRVMs model of hypertrophy, agonist-induced increases 


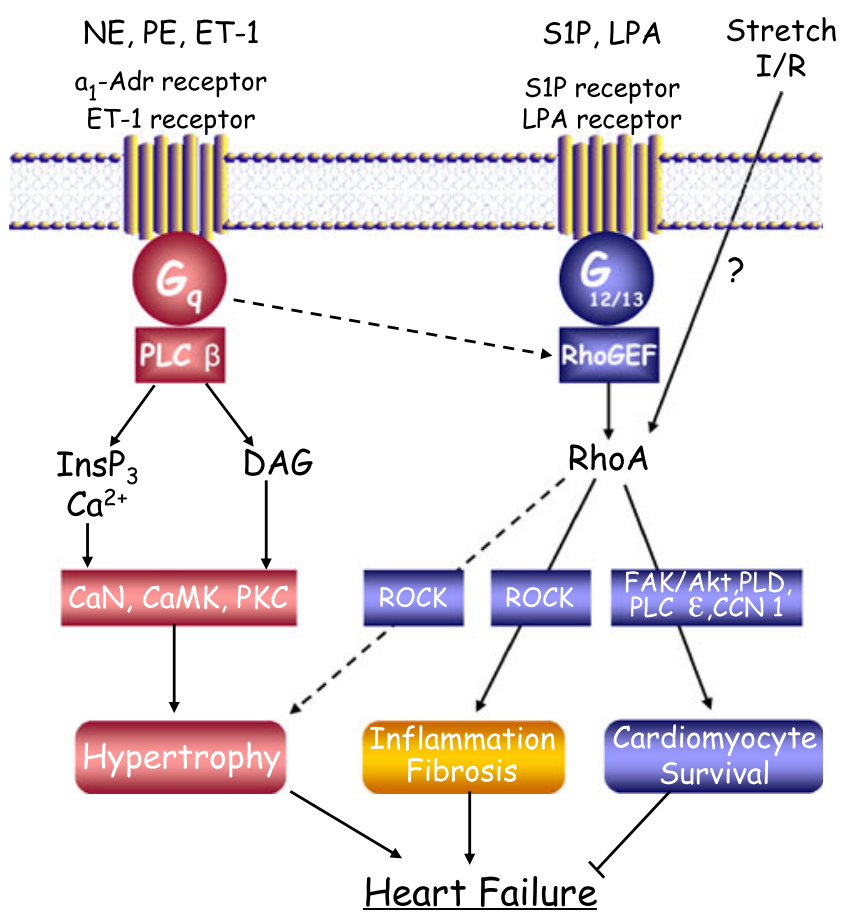

Fig. 1 GPCRs signaling in hypertrophy, survival, and failure. Dashed lines indicate pathways that the authors do not consider to be predominant. Abbreviations: NE norepinephrine, $P E$ phenylephrine, ET-1 endothelin-1, S1P sphingosine 1-phosphate, LPA lysophosphatidic acid, $I / R$ ischemia/reperfusion, InsP3 inositol-1,4,5-triphosphate, $D A G$ diacylglycerol, PLC phospholipase C, RhoGEF rho guanine nucleotide exchange factor, $\mathrm{PKC}$, protein kinase $\mathrm{C}, \mathrm{CaMK}$, calciumcalmodulin-dependent kinase, $C a N$, calcineurin, $R O C K$ rho-associated coiled-coil containing protein kinase, FAK focal adhesion kinase, $P L D$ phospholipase D

in cell size, protein expression, and actin organization (all hallmarks of hypertrophy) could be attenuated by treatment with the $\mathrm{C} 3$ exoenzyme, which ribosylates and inhibits RhoA function $[17,18]$, or by expression of a dominantnegative form of RhoA [19]. Hypertrophic effects of RhoA were demonstrated to be transduced through activation of Rho-associated coiled-coil containing protein kinase (ROCK), a well-characterized RhoA effector [20-24]. RhoA and ROCK have also been demonstrated to be transducers of hypertrophy induced by static or pulsatile stretch of NRVMs [25, 26]. Our laboratory showed involvement of RhoA in MAP kinase translocation to the nucleus and in cardiomyocyte enlargement induced by stretch [25], while others have demonstrated that stretch-induced regulation of hypertrophy-associated gene expression is abolished following transfection with RhoA antisense oligonucleotides [26].

RhoA and ROCK have also been implicated in hypertrophy induced by pressure overload (TAC) or in vivo agonist infusion. There is rapid activation of RhoA and ROCK in adult rat hearts subjected to pressure overload [27]. Moreover, recent work using a similar pressure overload model showed that ROCK inhibition reduced the hypertrophic response and collagen deposition (a result of fibrosis), as well as improving cardiac function [28]. Treatment with the ROCK inhibitor fasudil (HA-1077) also blunted the hypertrophic response to angiotensin II (Ang II) infusion in rats, a treatment associated with ROCK activation as assessed by phosphorylation of ezrin/radixin/ moesin (ERM) proteins [29]. These findings support the involvement of RhoA/ROCK signaling in development of hypertrophy in vivo.

The relative importance of, and relationship between, $\mathrm{G} \alpha_{\mathrm{q}}$ and RhoA signaling pathways in agonist and TACinduced hypertrophy has not been extensively analyzed. Is RhoA a downstream target of $\mathrm{G} \alpha_{\mathrm{q}}$ signaling or does RhoA initiate a distinct and parallel hypertrophic signaling pathway? We originally proposed that RhoA could be activated downstream of $\mathrm{G} \alpha_{\mathrm{q}}$ in NRVM hypertrophic pathways [19], although we had no specific mechanistic insights into how this would occur. RhoA is activated by guanine nucleotide exchange factors (GEFs), proteins that catalyze exchange of guanosine $5 c$-diphosphate (GDP) for guanosine $5 c$-triphosphate (GTP) on RhoA [30]. The GTPbound RhoA is the active form that interacts with and regulates effectors such as ROCK to elicit downstream responses [31, 32]. While it has been clear for many years that certain GPCR agonists can cause RhoA activation, the GEFs acting downstream of GPCRs have only recently been identified. Among these are GEFs such as the p63 rho GEF (RhoGEF), shown to bind and be regulated by $\mathrm{G} \alpha_{\mathrm{q}}$ [33-35]. Discovery of $G \alpha_{\mathrm{q}}$-regulated GEFs provides a means by which GPCRs that stimulate $\mathrm{G} \alpha_{\mathrm{q}}$ could also lead to RhoA activation and RhoA-mediated hypertrophy. Perhaps the newly discovered protective effects of cardiac $\alpha_{1}$ adrenergic receptors (Simpson, unpublished observations) reflect activation of a RhoA signaling pathway.

Notably, however, the best described hypertrophic agonists (NE, PE, and ET-1) are not nearly as efficacious at activating RhoA as are another set of ligands, including sphingosine 1-phosphate (S1P), lysophosphatidic acid (LPA), thrombin, and thromboxane A2. The receptors for this latter group of ligands couple not only to $\mathrm{G} \alpha_{\mathrm{q}}$ but also with high efficiency to the newest member of the heterotrimeric G-protein family, $\mathrm{G} \alpha_{12}$ and its family member $\mathrm{G} \alpha_{13}$ [36, 37]. Indeed, initial insights into how GPCRs activate RhoA emerged from seminal papers demonstrating that a particular GEF, the p115RhoGEF, interacts directly with $\mathrm{G} \alpha_{12}$ and $\mathrm{G} \alpha_{13}[38,39]$. It is now clear that the interaction of $\mathrm{G} \alpha_{12}$ or $\mathrm{G} \alpha_{13}$ with other RhoGEFs including leukemia-associated RhoGEF(LARG) and PDZ-RhoGEF leads to their activation $[30,40,41]$. There is also an A kinase-anchoring protein (AKAP-Lbc) that contains a RhoGEF domain and mediates RhoA activation in cardiomyocytes in response to agonists such as LPA and PE, 
$[42,43]$. It is now well accepted that much as the effector for $\mathrm{G} \alpha_{\mathrm{s}}$-coupled receptors is adenylate cyclase and that for $\mathrm{G} \alpha_{\mathrm{q}}$-coupled receptors is PLC $\beta$, RhoGEFs and RhoA activation serve as the primary effector for signaling by GPCRs that couple to $G \alpha_{12 / 13}$ proteins. Ligands such as S1P and LPA, by activating GPCRs that couple to $G \alpha_{12}$ or $G \alpha_{13}$ and hence to RhoGEFs, are very effective initiators of RhoA signaling pathways.

Interestingly, recent studies challenge the hypothesized role of $\mathrm{G} \alpha_{12 / 13}$, RhoA, and ROCK in development of hypertrophy. Expression of $\mathrm{G} \alpha_{12}$ in NRVMs has been shown to induce a hypertrophic response [18, 44, 45]. Moreover a recent study of transgenic mice engineered to express an inhibitor of $\mathrm{G} \alpha_{12 / 13}$ (RGS domain of p115GEF) in a cardiac-specific manner did not show decreases in hypertrophy in response to pressure overload [46]. Genetic deletion of $\mathrm{G} \alpha_{12 / 13}$ also fails to block hypertrophy in vivo (S. Offermanns, personal communication). These findings contrast with those of comparable experiments cited above in which TAC-induced hypertrophy was inhibited when $\mathrm{G} \alpha_{\mathrm{q}}$ signaling was prevented [12, 47]. Recent studies also show no inhibition of pressure overload-induced hypertrophy in mice in which ROCK1, the RhoA target suggested to mediate hypertrophy in NRVMs, is genetically deleted $[48,49]$. Several lines of evidence from our laboratory also argue that RhoA signaling does not lead to cardiac hypertrophy. For example, we observe no difference in hypertrophy induced by pressure overload in mice in which $\mathrm{S}_{1} \mathrm{P}_{2}$ or $\mathrm{S}_{1} \mathrm{P}_{3}$ receptors are genetically deleted, although we know that stimulation of S1P receptors leads to robust RhoA activation in cardiomyocytes $[50,51]$ and that RhoA activation occurs through $\mathrm{S}_{1} \mathrm{P}_{2}$ and/or $\mathrm{S}_{1} \mathrm{P}_{3}$ receptors [52]. We have also observed that cardiac-specific inducible RhoA expression does not lead to hypertrophy in mice followed for up to 1 year (Xiang et. al, manuscript in preparation). Thus, reevaluation with new models indicates that RhoA signaling is neither sufficient for the induction of cardiac hypertrophy nor necessary for that induced by pressure overload in vivo. If RhoA is not a critical player in development of in vivo hypertrophy, is there an alternative physiological role for RhoA activation and the agonists/ interventions that induce RhoA activation in the heart?

\section{Heart Failure}

Cardiac hypertrophic responses can become maladaptive if the initial cardiac insult persists. The mechanisms responsible for the transition from compensatory to maladaptive hypertrophy and remodeling are not well understood, although various molecular mechanisms have been suggested to underlie this transition. A role for RhoA activation in the transition from hypertrophy to dilation and heart failure is suggested by several in vivo findings. One is that a lethal dilated cardiomyopathy develops in cardiac-specific RhoA transgenic mice [53]. More recent studies using a tyrosine phosphatase knockout mouse also showed RhoA-mediated cardiac dilation, suggesting a role for RhoA in the development of cardiomyopathy [54]. Genetically altered mouse models have also implicated ROCK in the development of heart failure. Thus, whereas ROCK1 null and heterozygous null mice show no difference in development of hypertrophy following pressure overload or Ang II infusion, they have significantly less fibrosis and reduced expression of a variety of extracellular matrix (ECM) proteins and fibrogenic cytokines $[48,55]$. Similarly, there is improved cardiac function in the $\mathrm{G} \alpha_{\mathrm{q}}$ transgenic model of dilated cardiomyopathy when these mice are crossed with mice in which ROCK1 is deleted [49]. Taken together these studies implicate RhoA/ ROCK signaling in the transition from compensatory hypertrophy to heart failure.

Both expression and activity of RhoA and ROCK have been noted to increase in a variety of cardiovascular disease models, including myocardial infarction and pressure overload [27, 56-58]. ROCK1 is activated not only by RhoA binding but also through its cleavage, which is increased in human heart failure patients [59]. A maladaptive role of RhoA/ROCK signaling in the cardiovascular system in vivo is supported by several studies demonstrating that inhibitors of RhoA/ROCK diminish diastolic contractile dysfunction induced by pressure-overload or reperfusion injury [28, 60, 61]. Key to interpreting these findings, however, is that the sites for maladaptive ROCK signaling are not clearly defined. In studies using pharmacologic inhibitors of ROCK, as well as in conventional knockout mouse models, ROCK function would be inhibited not only in cardiomyocytes but also in fibroblasts, endothelial, and inflammatory cells. RhoA/ROCK signaling pathways are well-established mediators of changes in migration, proliferation, and gene expression in these cell types [62-66]. Accordingly, RhoA- and ROCK-mediated responses in noncardiomyocytes likely contribute to the detrimental effects of RhoA signaling in cardiovascular disease.

\section{Ischemic Injury}

Ischemia/reperfusion (I/R) damage occurs when interrupted blood flow is followed by restored circulation, resulting in oxidative stress, mitochondrial dysfunction, inflammation, and tissue damage. $\mathrm{I} / \mathrm{R}$ also activates numerous intracellular signaling pathways, some deleterious, but others protective [67]. We have observed marked activation of RhoA in response to $\mathrm{I} / \mathrm{R}$ in isolated perfused mouse hearts (Fig. 2). 


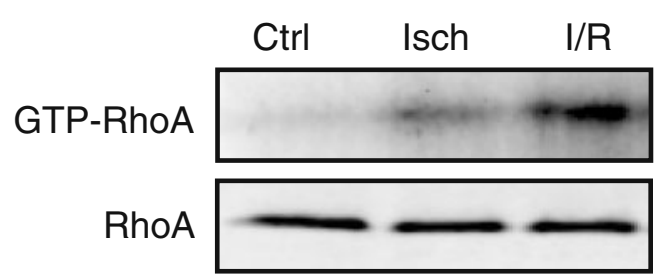

Fig. 2 RhoA is activated by ischemia/reperfusion in the perfused mouse heart. Isolated adult mouse hearts were retrograde perfused using the Langendorff method. Hearts were subjected to continuous perfusion (Ctrl), ischemia (Isch) for $30 \mathrm{~min}$, or ischemia for $30 \mathrm{~min}$ and reperfusion for $60 \mathrm{~min}(\mathrm{I} / \mathrm{R})$. Hearts were frozen, homogenized, and assessed for total RhoA in the lysate and activated RhoA based on pull-down with GST-rhotekin

Whether this occurs through activation of a RhoGEF in response to released mediators or as a direct result of oxidative stress is not known. Interestingly, a recent paper provided evidence that RhoA can be directly activated by reactive oxygen species, via a mechanism involving critical cysteine residues present in a redox-sensitive motif [68]. Published studies using an in vivo rat $\mathrm{I} / \mathrm{R}$ model demonstrate increased expression of RhoA and activity of ROCK following $30 \mathrm{~min}$ of coronary occlusion followed by $24 \mathrm{~h}$ of reperfusion [60]. In this model, infarct size was reduced by inhibiting ROCK with Y-27632. A similar study carried out using an in vivo mouse $\mathrm{I} / \mathrm{R}$ model also showed decreased infarct size and significantly less inflammation in mice treated with ROCK inhibitors compared with control, suggesting a deleterious role of RhoA/ROCK signaling in ischemic injury [61, 69].

What are the mechanisms by which ROCK inhibition could decrease $\mathrm{I} / \mathrm{R}$ injury? A recent study showed that infarct size was not diminished by Y-27632 when wortmannin or nitro-L-arginine methyl ester were also present, suggesting that protective PI3K/Akt/NO signaling pathways are necessary [61]. Another study demonstrated that I/ $\mathrm{R}$ decreased expression of the antiapoptotic Bcl-2 protein and that this did not occur in Y-27632-treated hearts [60]. Consistent with a role of ROCK in apoptosis, Y-27632treated animals showed reduced TUNEL-positive nuclei in the infarcted regions [61]. Inflammatory responses induced by $\mathrm{I} / \mathrm{R}$ are also abrogated by inhibition of ROCK with Y27632 suggesting that RhoA/ROCK effects on inflammatory gene expression contribute to cardiovascular injury after I/R[61, 69]. Finally ROCK inhibition with Y-27632 or fasudil (HA-1077) was shown to decrease fibrosis following myocardial infarction in both mouse and rat models [56, 58], indicating that ROCK contributes either directly or indirectly to proliferation of cardiac fibroblasts in ischemic disease. Thus, there are numerous sites and mechanisms through which Rho/ROCK signaling could be deleterious and account for the salutary effect of ROCK inhibitors on $I / R$ injury and development of heart failure.
RhoA Regulation of Cardiomyocyte Death and Survival

Cardiomyocyte loss by apoptosis and/or necrosis plays a crucial role in development of heart failure [70-72]. Our previous finding that cardiac-specific RhoA transgenic mice show spontaneous dilated cardiomyopathy [53] led us to hypothesize that cardiomyocyte cell death could be induced by sustained activity of RhoA. In subsequent work, we demonstrated that enhanced and sustained RhoA/ROCK signaling in NRVMs induces cardiomyocyte apoptosis [50]. Specifically, we demonstrated that expression of constitutively activated RhoA for $48-72 \mathrm{~h}$ activated a mitochondrial death pathway in association with a striking up-regulation, activation, and mitochondrial association of the proapoptotic Bcl family member, Bax [50].

Conversely, we found that more acute RhoA activation protected cardiomyocytes from apoptotic insult [51]. Expression of activated RhoA in NRVMs for less than $24 \mathrm{~h}$ did not induce apoptosis but rather protected cells against both peroxide and glucose deprivation-induced apoptosis. Protection was dependent on ROCK activity, cytoskeletal integrity, and the activation of focal adhesion kinase (FAK). FAK, which is known to be activated through integrin engagement with the ECM, has a number of distinct phosphorylation sites that enable binding to signaling molecules including Src, PI3K, and p130Cas [73, 74]. We demonstrated that the role of FAK as a protein scaffold is responsive to RhoA signaling in NRVMs, recruiting the p85 subunit of PI3K and activating the survival kinase Akt. Mechanical stretch, which has been shown to activate RhoA in cardiomyocytes, was also found to elicit FAK and Akt activation [26, 51]. Interestingly, cardiomyocyte-specific ablation of FAK increased infarct size and cardiomyocyte apoptosis in response to I/R [75], consistent with a role for FAK as a protective downstream target of RhoA signaling in cardiomyocytes (Fig. 3).

In summary, although there is much evidence that activation of ROCK is deleterious in the heart, RhoA may have the capacity to confer protection in cardiomyocytes by signaling through Akt or other effectors. Recent studies in cardiac and noncardiac cells have identified new targets through which activated RhoA can signal. These, as well as more established targets that have not been fully investigated, are described below as potential mediators of cardiomyocyte protection through RhoA signaling.

\section{RhoA and Phospholipid Signaling}

Phosphoinositide Synthesis

As described above, RhoA acts indirectly, through its wellknown effects on cytoskeletal remodeling and FAK, to 
Fig. 3 RhoA-mediated protective signaling through Akt

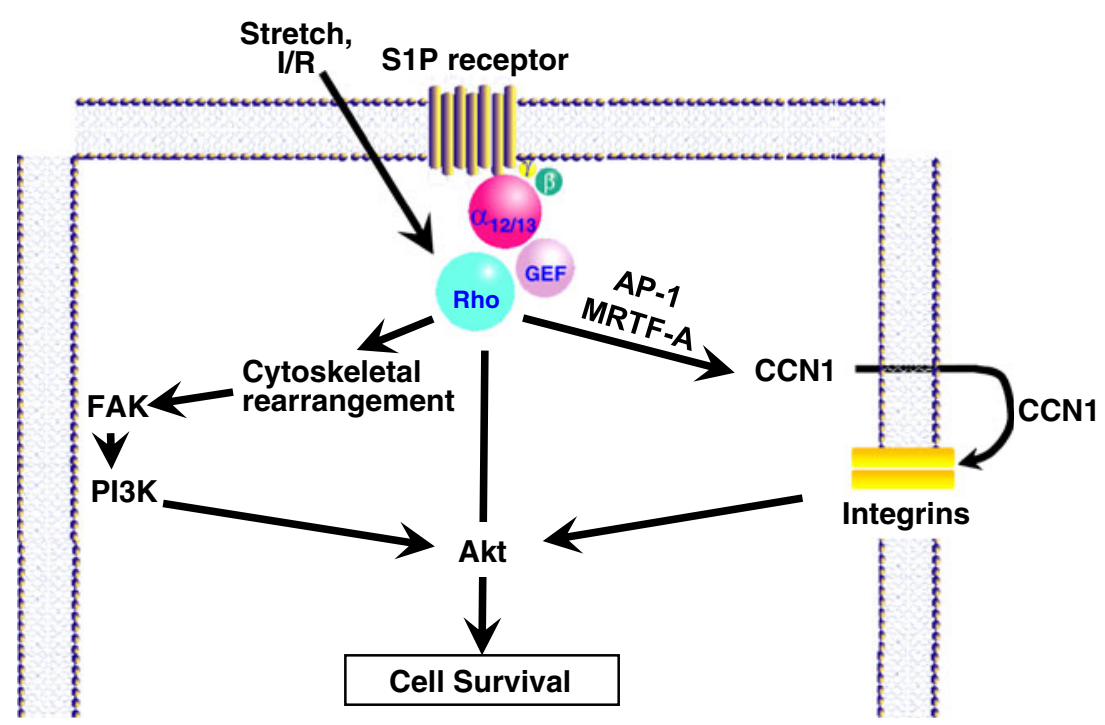

stimulate phosphoinositide signaling. There are, in addition, other phospholipid signaling pathways that are modulated through RhoA, several of which appear to be the direct result of RhoA interactions with phospholipid metabolizing enzymes (Fig. 4). One of the earliest effects described in mammalian cells was the regulation of phosphatidylinositol 4,5-bisphosphate $\left(\mathrm{PIP}_{2}\right)$ synthesis via effects of RhoA on the synthetic enzyme PIP-5 kinase [76, 77]. RhoA-mediated changes in the synthesis and hence the level of $\mathrm{PIP}_{2}$ can affect the ability of the cell to respond to integrins or GPCRs that signal via PLC- mediated PIP $_{2}$ hydrolysis [76, 78]. In addition to serving as a substrate for PLC, $\mathrm{PIP}_{2}$ subserves myriad cellular functions including regulation of ion channels and cytoskeletal proteins and recruitment of signaling molecules to the cell membrane. Thus, one hypothesis is that effects of RhoA on $\mathrm{PIP}_{2}$ levels can affect cell survival $[79,80]$.

\section{PLC Activation}

PLC epsilon (PLC $\varepsilon$ ), the newest member of the PLC family, is uniquely positioned to serve as an integrator of signaling from GPCRs and small GTPases [81, 82]. This isoform of PLC is directly regulated by binding of the small GTPases Rap1 and RhoA [83-88]. There is, in contrast, no regulation by $\mathrm{G} \alpha_{\mathrm{q}}$, the direct activator of the canonical PLC, PLC $\beta$ [89-91]. Accordingly PLC $\varepsilon$ is regulated by agonists that couple to $\mathrm{G} \alpha_{12 / 13}$ and $\mathrm{RhoA}$ rather than those that couple to $\mathrm{G} \alpha_{\mathrm{q}}[83,90]$. Another critical feature of $\mathrm{PLC} \varepsilon$ is that it contains an N-terminal CDC25 homology domain that functions as an exchange factor for small GTPases [85, 87, 92]. This allows the enzyme to function not only as a phospholipase (generating diacylglycerol [DAG] and inositol trisphosphate) but also as an activator of Rap1 (Fig. 4).
Two important functions downstream of Rap1 activation may be relevant to cardiomyocyte signaling. One is that active Rap 1 could feedback on and thus continue to activate PLC $\varepsilon$, contributing to sustained DAG production $[83,87$, 93]. DAG plays an important role in activation of $\mathrm{PKC}$ and studies from the Smrcka laboratory demonstrate that the novel $\mathrm{PKC}$ isoform, $\mathrm{PKC} \varepsilon$, is in fact activated through PLC $\varepsilon$ in the heart [94]. Rap1 also activates ERK, and we have shown that PLCE contributes to sustained agonist-

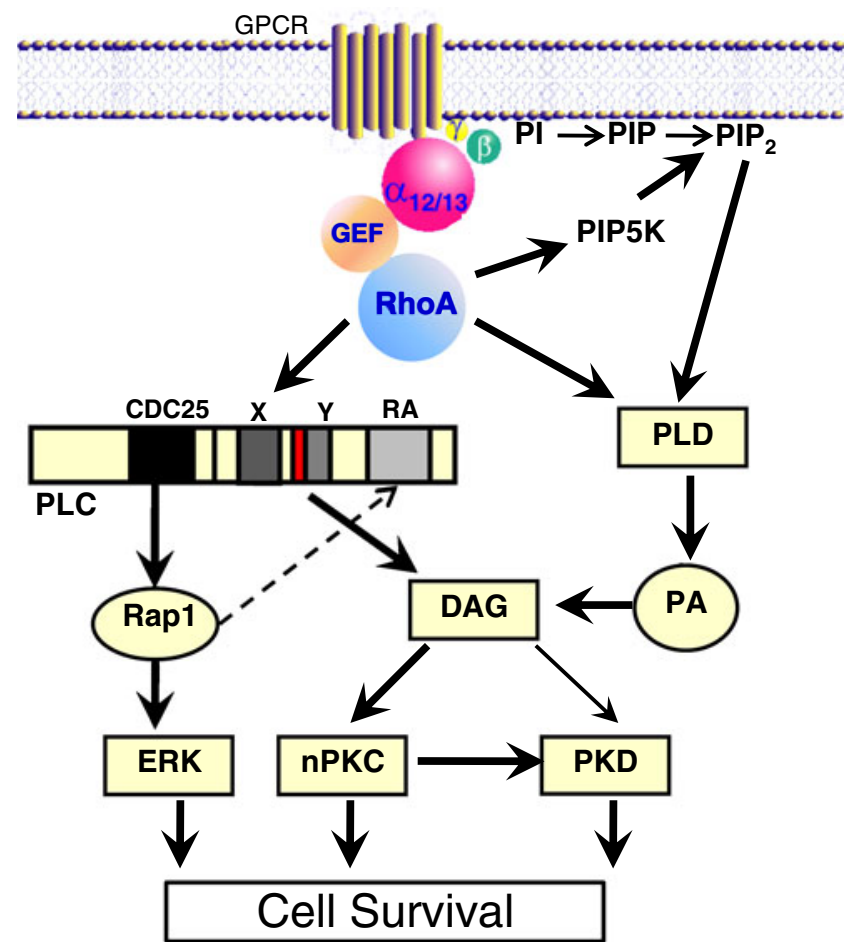

Fig. 4 RhoA-mediated protective signaling through phospholipid regulatory enzymes 
induced ERK activation [83]. There is considerable evidence that ERK signaling is protective in many cell types including cardiomyocytes [95-97], as is $\mathrm{PKC} \varepsilon$ [98102]. Thus, sustained activation of ERK or $\mathrm{PKC} \varepsilon$, resulting from activation of $\mathrm{PLC} \varepsilon$, could contribute to RhoA-mediated cardiomyocyte protection. Smrcka's laboratory also demonstrated that there is a significant level of PLC $\varepsilon$ expression in the heart and that PLC $\varepsilon$ is increased in human failing hearts and in animal models of pressure overload and isoproterenolinduced hypertrophy [103]. Their analysis of PLC $\varepsilon$ knockout mice revealed decreased $\beta$-adrenergic receptor-induced contractility. In addition, they saw enhanced pathological hypertrophy and fibrosis in PLC $\varepsilon$ knockout mice, leading to the suggestion that $\mathrm{PLC} \varepsilon$ protects against development of pathologic hypertrophy [103].

\section{Phospholipase D Activation}

While PLC activation is often considered to be the major mechanism for DAG generation, another phospholipase, phospholipase D (PLD) may be equally or more important. In contrast to PLC, PLD uses the more abundant phospholipid, phosphatidylcholine, as its substrate and initially produces phosphatidic acid (PA), which is then converted to DAG through the actions of lipid phosphatases (Fig. 4). Two mammalian PLD isozymes, PLD1 and PLD2, have been identified [33, 104-106]. There is abundant evidence that PLD1 (but not PLD2) is activated by the Rho family GTPases RhoA, Rac1, and Cdc42, with RhoA being the most efficacious [105, 107-109]. RhoA regulates PLD1 $[108,110-113]$ through direct interaction with its C-terminus [108, 110, 111, 114]. Activation of PLD1 could also occur indirectly through increased RhoA-mediated synthesis of $\mathrm{PIP}_{2}$, another critical cofactor for PLD activation $[78,112$, 115].

Roles for PLD/PA/DAG signaling in the myocardium, particularly in myocardial protection, have been suggested. Like the kinase pathways activated during $\mathrm{I} / \mathrm{R}$ and serving protective functions [67, 116-119], there is considerable evidence that oxidative stress activates and regulates PLD activity [120-126]. Activation of PLD in response to oxidative stress is associated with various cardiac pathologies, including coronary heart diseases [127-129]. PLD has been reported to be involved in cardioprotection by ischemic preconditioning, a phenomenon in which brief episodes of $\mathrm{I} / \mathrm{R}$ render the myocardium insensitive to a subsequent prolonged ischemic episode [130, 131]. Pharmacologically induced activation of PLD was shown to reduce infarct size, while inhibition of PLD blocked the beneficial effects of preconditioning in isolated rabbit and rat hearts $[130,131]$. Interestingly, adenosine-induced protection against I/R injury was suggested to be mediated through RhoA and a direct interaction with PLD1, as it was blocked by a mutant PLD1 that did not bind RhoA [132]. Thus, PLD1 activity appears to be involved in cardioprotection, although mechanisms for its activation and protective function have not been elucidated.

\section{Protein Kinase Activation and DAG}

As mentioned above, DAG generated through the actions of PLC or PLD activates PKC. PKC has been implicated in cardiac metabolism, contractile function, hypertrophy, heart failure, fibrosis, inflammation, and responses to ischemic injury. The predominant isozyme of PKC in the ventricle is $\operatorname{PKC} \alpha$, an isoform shown by Molkentin's group to play a role in heart failure susceptibility and cardiac contractility $[133,134]$. The novel PKC isozymes, $\mathrm{PKC} \varepsilon$ and $\mathrm{PKC} \delta$, have been suggested to play divergent roles in $\mathrm{I} / \mathrm{R}$ injury. $\mathrm{PKC} \varepsilon$ has been shown to confer cardioprotection against $\mathrm{I} / \mathrm{R}$ injury and to contribute to the protective effects of preconditioning [98-100, 135] and postconditioning [101, $136]$ in various animal models and in the human myocardium [102]. While some data also implicate PKC $\delta$ in cardioprotection [137], most evidence suggests that PKC $\delta$ is proapoptotic and has detrimental effects in the heart [138-142]. In the setting of I/R injury, it has been shown that either $\mathrm{PKC} \varepsilon$ activation or $\mathrm{PKC} \delta$ inhibition reduce $\mathrm{I} / \mathrm{R}$ damage, whereas $\mathrm{PKC} \varepsilon$ inhibition or $\mathrm{PKC} \delta$ activation increase injury [102, 140, 143]. Additionally, combined $\mathrm{PKC} \varepsilon$ activation and $\mathrm{PKC} \delta$ inhibition have been shown to exert additive protection against $\mathrm{I} / \mathrm{R}$ injury in isolated rat hearts [144].

\section{Protein Kinase D Activation}

Protein kinase D (PKD) is activated in the adult myocardium [145] and in other tissues through effects of novel PKCs [146-148]. There are a growing number of functions attributed to PKD signaling in the heart, including regulation of contractile function through phosphorylation of troponin-I [149, 150], and phosphorylation of HDAC-5, a class II HDAC, that regulates cardiac hypertrophy [151153]. In other systems, PKD has also been shown to function, via nuclear factor $\mathrm{KB}$ signaling, as a mediator of cell survival [154-156]. Notably, PKD activity has been reported to be regulated by RhoA. Expression of a constitutively activated RhoA increased basal PKD kinase activity in COS-7 cells [157] and induced PKD activationloop phosphorylation in HeLa cells [158]. RhoA-induced PKD activation was suggested to be mediated through ROCK and PKC $\varepsilon$ since treatment with the ROCK inhibitor Y-27632 or knockdown of PKC $\varepsilon$ (but not PKC $\delta$ ) by siRNA inhibited RhoA-induced PKD phosphorylation in HeLa cells [158]. A Rho/ROCK/PKC signaling pathway has also been reported to be upstream of PKD-induced protection 
against oxidative stress in intestinal epithelial cells [159]. A functional role of PKD for cardiac protection has not, to our knowledge, been demonstrated.

\section{RhoA and Gene Expression}

\section{RhoA and SRF}

Rho GTPases are best known for their role in regulation of cytoskeletal dynamics through effectors that control cell adhesion, morphology, and motility [160-169]. Rho GTPases also play a critical, albeit generally less appreciated role, in transcriptional regulation, as first noted based on RhoA-dependent regulation of serum response factor (SRF) target genes [170]. The SRF protein is constitutively localized to the nucleus and bound to serum response element (SRE) sequences, and no direct modifications of the protein are required for its function [171-174]. Rather SRF associates with other transcription factors to provide combinatorial control of its target genes [175]. Two major classes of coactivators, regulated by separate signaling pathways, are known to activate SRF: the ternary complex factors (TCFs) and the myocardin-related transcription factors (MRTFs) [176-179].

The TCF family is activated by MAP kinase-mediated phosphorylation [176, 179, 180]. However, Treisman's group showed that RhoA effects on SRF activity were mediated through a TCF independent pathway [170]. RhoA activation was also shown to stimulate $c$-fos SRE transcription in a TCF-independent manner [181]. In cardiomyocytes, we reported that RhoA affects ANF gene expression through TCF independent SRE sites [182]. Myocardin, MRTF-A and MRTF-B comprise the second, more recently characterized SRF coactivator family $[179,183,184]$. The activity of MRTF-A and MRTF-B depends on RhoA signaling and actin dynamics [179, 185-189]. Association of MRTF-A with G-actin results in its sequestration in the cytoplasm. Serum stimulation and other signals that activate RhoA promote actin polymerization $[188,190,191]$, leading to MRTF-A translocation into the nucleus and SRF target gene activation [179, 188, 192]. Immediate-early genes, SRF itself, skeletal $\alpha$-actin, and myosin light chain-2 (MLC-2v), are among the genes regulated in this manner [180, 193195]. Also notable among the SRF-regulated genes are the growth factor inducible immediate early genes CCN1 (Cyr61) and CCN2 (CTGF), which belong to the CCN family of matricellular proteins [196-199].

\section{RhoA and CCN1/Cyr61}

CCN1 was first identified as an immediate early gene upregulated in response to growth factors and subsequently determined to be secreted from the cell, where it serves a function intermediate between that of ECM proteins and growth factors [200-202]. CCN1 is a pleiotropic molecule, acting via cell surface integrin engagement to regulate cell migration, proliferation, and survival [197, 198, 203, 204]. Mechanical stretch induces CCN1 expression [205-207], and recent studies showed that MRTF-A and CREB binding proteins are required for mechanical straininduced transcriptional activation of the CCN1 gene in vitro and in vivo [207, 208](see Fig. 3). Mechanical overload-induced CCN1 gene expression in vivo was also associated with RhoA-mediated nuclear localization of MRTF-A and enrichment of SRE sites on the CCN1 promoter with MRTF-A and acetylated histone H3.

\section{CCN1 in the Heart}

Little is known about the regulation or role of CCN1 in the heart, but several papers report that CCN1 expression is highly expressed in the myocardium of patients with heart failure or ischemic myopathy [209-211]. CCN1 expression has also been shown to increase in mouse heart in response to pressure overload and myocardial infarction and in cardiomyocytes stimulated by GPCR agonists [211]. Multiple signaling pathways including activation of ERK and PKC can contribute to induction of CCN1 expression [211]. In addition, there is considerable evidence that signaling through RhoA plays a major role in CCN1 induction in response to S1P and other agonists in cardiomyocytes (Zhao et. al., manuscript in preparation) as in other cell types [204, 205, 208, 212, 213]. A paper by Yoshida et al. [214] provides intriguing evidence supporting the hypothesis that $\mathrm{CCN} 1$ is cardioprotective. These investigators observed that CCN1 addition to isolated cardiomyocytes attenuated the response to oxidative stress and that this occurred via CCN1 effects on integrin $\beta 1$-mediated FAK and Akt activation. Thus, RhoA-mediated increases in $\mathrm{CCN} 1$ expression and release are a potential mechanism by which the cell can further activate integrins, FAK, and protective Akt signals (see Fig. 3).

\section{Conclusion}

One of the challenges faced by maturing scientists is that of remembering what we published and defended in the past and squaring it with our more recent findings and made by our colleagues. The solace is that the old theories advanced the field to the stage where they can now be revisited and revised using more sophisticated approaches. The notion that RhoA serves as a mediator of cardiac hypertrophy, one that we proposed and others espoused a decade ago, is not wrong, but the role of RhoA in this response appears minor 
by comparison with that of other pathways shown to be essential and efficacious hypertrophic mediators. Pharmacologic inhibitors of ROCK have been developed in the last decade and have proven to be remarkable tools for further discovery, including demonstration that vascular tone is regulated by biochemically defined RhoA/ROCK pathways. These inhibitors have since been shown to be useful in treating a plethora of cardiovascular pathologies, from hypertension to atherosclerosis, and from heart failure to ischemic damage. While targets for the effects of ROCK inhibitors may be known, the cellular site of their action is not. Indeed, a notion we propose here is that whereas chronic RhoA signaling through ROCK may be a villain in inflammatory cells, fibroblasts, endothelial cells, and vascular smooth muscle, more acute activation of RhoA, at least within the cardiomyocyte, may serve to promote survival. There is evidence that RhoA is protective in a number of contexts, and there are multiple potential direct targets for RhoA that could mediate such responses. We suggest that RhoA is activated in the myocyte along with other protective pathways and that its effects on the cytoskeleton, phospholipids, or gene expression could be used to aid the ailing myocyte. If salutary pathways can be uncovered, they would be potential targets for cardioprotection. Accordingly, a prudent approach to treating conditions such as ischemic heart diseases might be to avoid the use of RhoA/ROCK inhibitors during the earliest phases of ischemic injury.

Open Access This article is distributed under the terms of the Creative Commons Attribution Noncommercial License which permits any noncommercial use, distribution, and reproduction in any medium, provided the original author(s) and source are credited.

\section{References}

1. Simpson, P. (1983). Norepinephrine-stimulated hypertrophy of cultured rat myocardial cells is an $\alpha_{1}$-adrenergic response. Journal of Clinical Investigation, 72, 732.

2. Shubeita, H. E., McDonough, P. M., Harris, A. N., Knowlton, K. U., Glembotski, C. C., Brown, J. H., et al. (1990). Endothelin induction of inositol phospholipid hydrolysis, sarcomere assembly, and cardiac gene expression in ventricular myocytes: a paracrine mechanism for myocardial cell hypertrophy. The Journal of Biological Chemistry, 265, 20555.

3. Simpson, P., McGrath, A., \& Savion, S. (1982). Myocyte hypertrophy in neonatal rat heart cultures and its regulation by serum and by catecholamines. Circulation Research, 51, 787.

4. Knowlton, K. U., Michel, M. C., Itani, M., Shubeita, H. E., Ishihara, K., Brown, J. H., et al. (1993). The $\alpha$ la-adrenergic receptor subtype mediates biochemical, molecular, and morphologic features of cultured myocardial cell hypertrophy. The Journal of Biological Chemistry, 268, 15374.

5. Bogoyevitch, M. A., Glennon, P. E., Andersson, M. B., Clerk, A., Lazou, A., Marshall, C. J., et al. (1994). Endothelin-1 and fibroblast growth factors stimulate the mitogen-activated protein kinase signaling cascade in cardiac myocytes. The Journal of Biological Chemistry, 269, 1110.

6. McDonough, P. M., Brown, J. H., \& Glembotski, C. C. (1993). Phenylephrine and endothelin differentially stimulate cardiac PI hydrolysis and ANF expression. The American Journal of Physiology, 264, H625.

7. Ito, H., Hirata, Y., Adachi, S., Tanaka, M., Tsujino, M., Koike, A., et al. (1993). Endothelin-1 is an autocrine/paracrine factor in the mechanism of angiotensin II-induced hypertrophy in cultured rat cardiomyocytes. Journal of Clinical Investigation, 92, 398.

8. D'Angelo, D. D., Sakata, Y., Lorenz, J. N., Boivin, G. P., Walsh, R. A., Liggett, S. B., et al. (1997). Transgenic G $\alpha_{\mathrm{q}}$ overexpression induces cardiac contractile failure in mice. Proceedings of the National Academy of Sciences of the United States of America, 94, 8121.

9. Dorn, G. W., \& Brown, J. H. (1999). $\mathrm{G}_{\mathrm{q}}$ signaling in cardiac adaptation and maladaptation. Trends in Cardiovascular Medicine, 9, 26.

10. Adams, J. W., Sakata, Y., Davis, M. G., Sah, V. P., Wang, Y., Liggett, S. B., et al. (1998). Enhanced $\mathrm{G} \alpha_{\mathrm{q}}$ signaling: A common pathway mediates cardiac hypertrophy and apoptotic heart failure. Proceedings of the National Academy of Sciences of the United States of America, 95, 10140.

11. Akhter, S. A., Luttrell, L. M., Rockman, H. A., Iaccarino, G., Lefkowitz, R. J., \& Koch, W. J. (1998). Targeting the receptor$\mathrm{G}_{\mathrm{q}}$ interface to inhibit in vivo pressure overload myocardial hypertrophy. Science, 280, 574.

12. Wettschureck, N., Rutten, H., Zywietz, A., Gehring, D., Wilkie, T. M., Chen, J., et al. (2001). Absence of pressure overload induced myocardial hypertrophy after conditional inactivation of $\mathrm{G} \alpha_{\mathrm{q}} / \mathrm{G} \alpha_{11}$ in cardiomyocytes. Natural Medicines, 7, 1236.

13. Smrcka, A. V., Hepler, J. R., Brown, K. O., \& Sternweis, P. C. (1991). Regulation of polyphosphoinositide-specific phospholipase $\mathrm{C}$ activity by purified $\mathrm{G}_{\mathrm{q}}$. Science, 251, 804 .

14. Taylor, S. J., Chae, H. Z., Rhee, S. G., \& Exton, J. H. (1991). Activation of the $\beta 1$ isozyme of phospholipase $C$ by $\alpha$ subunits of the $\mathrm{G}_{\mathrm{q}}$ class of $\mathrm{G}$ proteins. Nature, 350, 516 .

15. Dorn, G. W., \& Force, T. (2005). Protein kinase cascades in the regulation of cardiac hypertrophy. Journal of Clinical Investigation, 115, 527.

16. Heineke, J., \& Molkentin, J. D. (2006). Regulation of cardiac hypertrophy by intracellular signalling pathways. Nature Reviews. Molecular Cell Biology, 7, 589.

17. Thorburn, J., Xu, S., \& Thorburn, A. (1997). MAP kinase- and Rho-dependent signals interact to regulate gene expression but not actin morphology in cardiac muscle cells. The EMBO Journal, 16, 1888.

18. Maruyama, Y., Nishida, M., Sugimoto, Y., Tanabe, S., Turner, J. H., Kozasa, T., et al. (2002). G $\alpha_{12 / 13}$ mediates $\alpha_{1}$-adrenergic receptorinduced cardiac hypertrophy. Circulation Research, 91, 961.

19. Sah, V. P., Hoshijima, M., Chien, K. R., \& Brown, J. H. (1996). Rho is required for $\mathrm{G} \alpha \mathrm{q}$ and $\alpha 1$-adrenergic receptor signaling in cardiomyocytes. Dissociation of Ras and Rho pathways. Journal of Biological Chemistry, 271, 31185.

20. Amano, M., Fukata, Y., \& Kaibuchi, K. (2000). Regulation and functions of Rho-associated kinase. Experimental Cell Research, $261,44$.

21. Noma, K., Oyama, N., \& Liao, J. K. (2006). Physiological role of ROCKs in the cardiovascular system. American Journal of Physiology. Cell Physiology, 290, C661.

22. Chaulet, H., Desgranges, C., Renault, M. A., Dupuch, F., Ezan, G., Peiretti, F., et al. (2001). Extracellular nucleotides induce arterial smooth muscle cell migration via osteopontin. Circulation Research, 89, 772.

23. Hoshijima, M., Sah, V. P., Wang, Y., Chien, K. R., \& Brown, J. H. (1998). The low molecular weight GTPase Rho regulates 
myofibril formation and organization in neonatal rat ventricular myocytes: Involvement of Rho kinase. The Journal of Biological Chemistry, 273, 7725.

24. Yanazume, T., Hasegawa, K., Wada, H., Morimoto, T., Abe, M., Kawamura, T., et al. (2002). Rho/ROCK pathway contributes to the activation of extracellular signal-regulated kinase/GATA-4 during myocardial cell hypertrophy. The Journal of Biological Chemistry, 277, 8618.

25. Kawamura, S., Miyamoto, S., \& Brown, J. H. (2003). Initiation and transduction of stretch-induced RhoA and Racl activation through caveolae: Cytoskeletal regulation of ERK translocation. The Journal of Biological Chemistry, 278, 31111.

26. Torsoni, A. S., Marin, T. M., Velloso, L. A., \& Franchini, K. G. (2005). RhoA/ROCK signaling is critical to FAK activation by cyclic stretch in cardiac myocytes. American Journal of Physiology. Heart and Circulatory Physiology, 289, H1488.

27. Torsoni, A. S., Fonseca, P. M., Crosara-Alberto, D. P., \& Franchini, K. G. (2003). Early activation of p160ROCK by pressure overload in rat heart. American Journal of Physiology. Cell Physiology, 284, C1411.

28. Phrommintikul, A., Tran, L., Kompa, A., Wang, B., Adrahtas, A., Cantwell, D., et al. (2008). Effects of a Rho kinase inhibitor on pressure overload induced cardiac hypertrophy and associated diastolic dysfunction. American Journal of Physiology. Heart and Circulatory Physiology, 294, H1804.

29. Higashi, M., Shimokawa, H., Hattori, T., Hiroki, J., Mukai, Y., Morikawa, K., et al. (2003). Long-term inhibition of Rho-kinase suppresses angiotensin II-induced cardiovascular hypertrophy in rats in vivo: Effect on endothelial $\mathrm{NAD}(\mathrm{P}) \mathrm{H}$ oxidase system. Circulation Research, 93, 767.

30. Rossman, K. L., Der, C. J., \& Sondek, J. (2005). GEF means go: Turning on RHO GTPases with guanine nucleotide-exchange factors. Nature Reviews. Molecular Cell Biology, 6, 167.

31. Loirand, G., Guerin, P., \& Pacaud, P. (2006). Rho kinases in cardiovascular physiology and pathophysiology. Circulation Research, 98, 322.

32. Brown, J. H., Del Re, D. P., \& Sussman, M. A. (2006). The Rac and Rho hall of fame: A decade of hypertrophic signaling hits. Circulation Research, 98, 730.

33. Kodaki, T., \& Yamashita, S. (1997). Cloning, expression, and characterization of a novel phospholipase D complementary DNA from rat brain. The Journal of Biological Chemistry, 272, 11408.

34. Rojas, R. J., Yohe, M. E., Gershburg, S., Kawano, T., Kozasa, T., \& Sondek, J. (2007). G $\alpha q$ directly activates p63RhoGEF and Trio via a conserved extension of the Dbl homology-associated pleckstrin homology domain. The Journal of Biological Chemistry, 282, 29201

35. Lutz, S., Freichel-Blomquist, A., Yang, Y., Ruemenapp, U., Jakobs, K. H., Schmidt, M., et al. (2005). The guanine nucleotide exchange factor p63Rho. Journal of Biological Chemistry

36. Riobo, N. A., \& Manning, D. R. (2005). Receptors coupled to heterotrimeric $\mathrm{G}$ proteins of the $\mathrm{G}_{12}$ family. Trends in Pharmacological Sciences, 26, 146.

37. Strathmann, M. P., \& Simon, M. I. (1993). $G \alpha_{12}$ and $G \alpha_{13}$ subunits define a fourth class of $\mathrm{G}$ protein $\alpha$ subunits. Proceedings of the National Academy of Sciences of the United States of America, 88, 5582.

38. Kozasa, T., Jiang, X., Hart, M. J., Sternweis, P. M., Singer, W. D., Gilman, A. G., et al. (1998). p115 RhoGEF, a GTPase activating protein for $\mathrm{G} \alpha_{12}$ and $\mathrm{G} \alpha_{13}$. Science, 280, 2109.

39. Hart, M. J., Jiang, X., Kozasa, T., Roscoe, W., Singer, W. D., Gilman, A. G., et al. (1998). Direct stimulation of the guanine nucleotide exchange activity of $\mathrm{p} 115 \mathrm{RhoGEF}$ by $\mathrm{G} \alpha_{13}$. Science, 280,2112

40. Lezoualc'h, F., Metrich, M., Hmitou, I., Duquesnes, N., \& Morel, E. (2008). Small GTP-binding proteins and their regulators in cardiac hypertrophy. Journal of Molecular and Cellular Cardiology, 44, 623-632.

41. Aittaleb, M., Boguth, C. A., \& Tesmer, J. J. (2009). Structure and function of heterotrimeric $\mathrm{g}$ protein-regulated rho guanine nucleotide exchange factors. Molecular Pharmacology, 77, 111-125.

42. Diviani, D., Soderling, J., \& Scott, J. D. (2001). AKAP-Lbc anchors protein kinase $\mathrm{A}$ and nucleates $\mathrm{G} \alpha_{12}$-selective Rhomediated stress fiber formation. The Journal of Biological Chemistry, 276, 44247.

43. Appert-Collin, A., Cotecchia, S., Nenniger-Tosato, M., Pedrazzini, T., \& Diviani, D. (2007). The A-kinase anchoring protein (AKAP)-Lbc-signaling complex mediates $\alpha 1$ adrenergic receptor-induced cardiomyocyte hypertrophy. Proceedings of the National Academy of Sciences of the United States of America, 104, 10140.

44. Finn, S. G., Plonk, S. G., \& Fuller, S. J. (1999). G $\alpha_{13}$ stimulates gene expression and increases cell size in cultured neonatal rat ventricular myocytes. Cardiovascular Research, 42, 140.

45. Arai, K., Maruyama, Y., Nishida, M., Tanabe, S., Takagahara, S., Kozasa, T., et al. (2003). Differential requirement of $\mathrm{G} \alpha_{12}, \mathrm{G} \alpha_{13}$, $\mathrm{G} \alpha_{\mathrm{q}}$, and $\mathrm{G} \beta \gamma$ for endothelin-1-induced c-Jun NH2-terminal kinase and extracellular signal-regulated kinase activation. Molecular Pharmacology, 63, 478.

46. Nishida, M., Sato, Y., Uemura, A., Narita, Y., Tozaki-Saitoh, H., Nakaya, M., et al. (2008). P2Y6 receptor-G $\alpha 12 / 13$ signalling in cardiomyocytes triggers pressure overload-induced cardiac fibrosis. The EMBO Journal, 27, 3104.

47. Esposito, G., Prasad, S. V., Rapacciuolo, A., Mao, L., Koch, W. J., \& Rockman, H. A. (2001). Cardiac overexpression of a G(q) inhibitor blocks induction of extracellular signal-regulated kinase and c-Jun $\mathrm{NH}(2)$-terminal kinase activity in in vivo pressure overload. Circulation, 103, 1453.

48. Zhang, Y. M., Bo, J., Taffet, G. E., Chang, J., Shi, J., Reddy, A. K., et al. (2006). Targeted deletion of ROCK1 protects the heart against pressure overload by inhibiting reactive fibrosis. The FASEB Journal, 20, 916.

49. Shi, J., Zhang, Y. W., Summers, L. J., Dorn, G. W., \& Wei, L. (2008). Disruption of ROCK1 gene attenuates cardiac dilation and improves contractile function in pathological cardiac hypertrophy. Journal of Molecular and Cellular Cardiology, 44, 551.

50. Del Re, D. P., Miyamoto, S., \& Brown, J. H. (2007). RhoA/Rho kinase upregulate Bax to activate a mitochondrial death pathway and induce cardiomyocyte apoptosis. The Journal of Biological Chemistry, 282, 8069.

51. Del Re, D. P., Miyamoto, S., \& Brown, J. H. (2008). Focal adhesion kinase as a RhoA-activable signaling scaffold mediating Akt activation and cardiomyocyte protection. The Journal of Biological Chemistry, 283, 35622.

52. Ishii, I., Ye, X., Friedman, B., Kawamura, S., Contos, J. J. A., Kingsbury, M. A., et al. (2002). Marked perinatal lethality and cellular signaling deficits in mice null for the two sphingosine 1phosphate receptors, $\mathrm{S}_{1} \mathrm{P}_{2} / \mathrm{LP}_{\mathrm{B} 2} / \mathrm{EDG}-5$ and $\mathrm{S}_{1} \mathrm{P}_{3} / \mathrm{LP}_{\mathrm{B} 3} / \mathrm{EDG}-3$. The Journal of Biological Chemistry, 277, 25152.

53. Sah, V. P., Minamisawa, S., Tam, S. P., Wu, T. H., Dorn, G. W., Ross, J., Jr., et al. (1999). Cardiac-specific overexpression of RhoA results in sinus and atrioventricular nodal dysfunction and contractile failure. Journal of Clinical Investigation, 103, 1627.

54. Kontaridis, M. I., Yang, W., Bence, K. K., Cullen, D., Wang, B., Bodyak, N., et al. (2008). Deletion of Ptpn11 (Shp2) in cardiomyocytes causes dilated cardiomyopathy via effects on the extracellular signal-regulated kinase/mitogen-activated protein kinase and RhoA signaling pathways. Circulation, 117, 1423.

55. Rikitake, Y., Oyama, N., Wang, C. Y., Noma, K., Satoh, M., Kim, H. H., et al. (2005). Decreased perivascular fibrosis but not cardiac hypertrophy in ROCK $1^{+/-}$haploinsufficient mice. Circulation, 112, 2959. 
56. Kobayashi, N., Horinaka, S., Mita, S., Nakano, S., Honda, T., Yoshida, K., et al. (2002). Critical role of Rho-kinase pathway for cardiac performance and remodeling in failing rat hearts. Cardiovascular Research, 55, 757.

57. Satoh, S., Ueda, Y., Koyanagi, M., Kadokami, T., Sugano, M., Yoshikawa, Y., et al. (2003). Chronic inhibition of Rho kinase blunts the process of left ventricular hypertrophy leading to cardiac contractile dysfunction in hypertension-induced heart failure. Journal of Molecular and Cellular Cardiology, 35, 59.

58. Hattori, T., Shimokawa, H., Higashi, M., Hiroki, J., Mukai, Y., Tsutsui, H., et al. (2004). Long-term inhibition of Rho-kinase suppresses left ventricular remodeling after myocardial infarction in mice. Circulation, 109, 2234.

59. Chang, J., Xie, M., Shah, V. R., Schneider, M. D., Entman, M. L., Wei, L., et al. (2006). Activation of Rho-associated coiledcoil protein kinase 1 (ROCK-1) by caspase-3 cleavage plays an essential role in cardiac myocyte apoptosis. Proceedings of the National Academy of Sciences of the United States of America, 103, 14495.

60. Bao, W., Hu, E., Tao, L., Boyce, R., Mirabile, R., Thudium, D. T., et al. (2004). Inhibition of Rho-kinase protects the heart against ischemia/reperfusion injury. Cardiovascular Research, 61, 548.

61. Hamid, S. A., Bower, H. S., \& Baxter, G. F. (2007). Rho kinase activation plays a major role as a mediator of irreversible injury in reperfused myocardium. American Journal of Physiology. Heart and Circulatory Physiology, 292, H2598.

62. Sahai, E., Alberts, A. S., \& Treisman, R. (1998). RhoA effector mutants reveal distinct effector pathways for cytoskeletal reorganization. SRF activation and transformation. EMBO Journal, 17, 1350.

63. Nelson, C. M., Pirone, D. M., Tan, J. L., \& Chen, C. S. (2004). Vascular endothelial-cadherin regulates cytoskeletal tension, cell spreading, and focal adhesions by stimulating RhoA. Molecular Biology of the Cell, 15, 2943.

64. Zhao, Z., \& Rivkees, S. A. (2004). Rho-associated kinases play a role in endocardial cell differentiation and migration. Developmental Biology, 275, 183.

65. Rikitake, Y., \& Liao, J. K. (2005). Rho-kinase mediates hyperglycemia-induced plasminogen activator inhibitor-1 expression in vascular endothelial cells. Circulation, 111, 3261.

66. Alblas, J., Ulfman, L., Hordijk, P., \& Koenderman, L. (2001). Activation of Rhoa and ROCK are essential for detachment of migrating leukocytes. Molecular Biology of the Cell, 12, 2137.

67. Murphy, E., \& Steenbergen, C. (2008). Mechanisms underlying acute protection from cardiac ischemia-reperfusion injury. Physiological Reviews, 88, 581.

68. Aghajanian, A., Wittchen, E. S., Campbell, S. L., \& Burridge, K. (2009). Direct activation of RhoA by reactive oxygen species requires a redox-sensitive motif. PLoS ONE, 4, 38045.

69. Wolfrum, S., Dendorfer, A., Rikitake, Y., Stalker, T. J., Gong, Y., Scalia, R., et al. (2004). Inhibition of Rho-kinase leads to rapid activation of phosphatidylinositol 3-kinase/protein kinase Akt and cardiovascular protection. Arteriosclerosis, Thrombosis, and Vascular Biology, 24, 1842.

70. Adams, J. W., \& Brown, J. H. (2001). G-proteins in growth and apoptosis: Lessons from the heart. Oncogene, 20, 1626.

71. Foo, R. S., Mani, K., \& Kitsis, R. N. (2005). Death begets failure in the heart. Journal of Clinical Investigation, 115, 565.

72. Dorn, G. W. (2009). Apoptotic and non-apoptotic programmed cardiomyocyte death in ventricular remodelling. Cardiovascular Research, 81, 465.

73. Parsons, J. T. (2003). Focal adhesion kinase: The first ten years. Journal of Cell Science, 116, 1409.

74. Mitra, S. K., \& Schlaepfer, D. D. (2006). Integrin-regulated FAK-Src signaling in normal and cancer cells. Current Opinion in Cell Biology, 18, 516.
75. Hakim, Z. S., DiMichele, L. A., Rojas, M., Meredith, D., Mack, C. P., \& Taylor, J. M. (2009). FAK regulates cardiomyocyte survival following ischemia/reperfusion. Journal of Molecular and Cellular Cardiology, 46, 241.

76. Chong, L. D., Traynor-Kaplan, A., Bokoch, G. M., \& Schwartz, M. A. (1994). The small GTP-binding protein Rho regulates a phosphatidylinositol 4-phosphate 5-kinase in mammalian cells. Cell, 79, 507.

77. Ren, X.-D., Bokoch, G. M., Traynor-Kaplan, A., Jenkins, G. H., Anderson, R. A., \& Schwartz, M. A. (1996). Physical association of the small GTPase Rho with a 68-kDa phosphatidylinositol 4phosphate 5-kinase in Swiss 3T3 cells. Molecular Biology of the Cell, 7, 435.

78. Schmidt, M., Bienek, C., Rumenapp, U., Zhang, C., Lummen, G., Jakobs, K. H., et al. (1996). A role for Rho in receptorand $\mathrm{G}$ protein-stimulated phospholipase C. Reduction in phosphatidylinositol 4, 5-bisphosphate by Clostridium difficile toxin b. Naunyn-Schmiedeberg's Archives of Pharmacology, 354, 87.

79. Mejillano, M., Yamamoto, M., Rozelle, A. L., Sun, H.-Q., Wang, X., \& Yin, H. L. (2000). Regulation of apoptosis by phosphatidylinositol 4,5 bisphosphate, inhibition of caspases, and caspase inactivation of phosphatidylinositol phosphate 5 kinases. Journal of Biological Chemistry, In Press.

80. Howes, A. L., Arthur, J. F., Zhang, T., Miyamoto, S., Adams, J. W., Dorn, G. W., II, et al. (2003). Akt-mediated cardiomyocyte survival pathways are compromised by G $\alpha$ q-induced phosphoinositide 4, 5-bisphosphate depletion. The Journal of Biological Chemistry, 278, 40343.

81. Wing, M. R., Bourdon, D. M., \& Harden, T. K. (2003). PLC- $\varepsilon$ : A shared effector protein in Ras-, Rho-, and G $\alpha \beta \gamma$-mediated signaling. Molecular Interventions, 3, 273.

82. Bunney, T. D., \& Katan, M. (2006). Phospholipase C $\varepsilon$ : Linking second messengers and small GTPases. Trends in Cell Biology, 16, 640.

83. Citro, S., Malik, S., Oestreich, E. A., Radeff-Huang, J., Kelley, G. G., Smrcka, A. V., et al. (2007). Phospholipase C $\varepsilon$ is a nexus for Rho and Rap-mediated G protein-coupled receptor-induced astrocyte proliferation. Proceedings of the National Academy of Sciences of the United States of America, 104, 15543.

84. Wing, M. R., Snyder, J. T., Sondek, J., \& Harden, T. K. (2003). Direct activation of phospholipase $\mathrm{C}-\varepsilon$ by Rho. The Journal of Biological Chemistry, 278, 41253.

85. Kelley, G. G., Reks, S. E., \& Smrcka, A. V. (2004). Hormonal regulation of phospholipase $\mathrm{C} \varepsilon$ through distinct and overlapping pathways involving $\mathrm{G}_{12}$ and Ras family G-proteins. The Biochemical Journal, 378, 129.

86. Song, C., Hu, C. D., Masago, M., Kariyai, K., YamawakiKataoka, Y., Shibatohge, M., et al. (2001). Regulation of a novel human phospholipase C, PLC $\varepsilon$, through membrane targeting by Ras. The Journal of Biological Chemistry, 276, 2752.

87. Jin, T. G., Satoh, T., Liao, Y., Song, C., Gao, X., Kariya, K., et al. (2001). Role of the CDC25 homology domain of phospholipase $\mathrm{C} \varepsilon$ in amplification of Rap1-dependent signaling. The Journal of Biological Chemistry, 276, 30301.

88. Schmidt, M., Evellin, S., Weernink, P. A., von Dorp, F., Rehmann, H., Lomasney, J. W., et al. (2001). A new phospholipase-C-calcium signalling pathway mediated by cyclic AMP and a Rap GTPase. Nature Cell Biology, 3, 1020.

89. Kelley, G. G., Reks, S. E., Ondrako, J. M., \& Smrcka, A. V. (2001). Phospholipase $\mathrm{C} \varepsilon$ : A novel Ras effector. The EMBO Journal, 20, 743.

90. Lopez, I., Mak, E. C., Ding, J., Hamm, H. E., \& Lomasney, J. W. (2001). A novel bifunctional phospholipase $\mathrm{C}$ that is regulated by $\mathrm{G} \alpha 12$ and stimulates the Ras/mitogen-activated protein kinase pathway. The Journal of Biological Chemistry, 276, 2758. 
91. Hains, M. D., Wing, M. R., Maddileti, S., Siderovski, D. P., \& Harden, T. K. (2006). G $\alpha_{12 / 13^{-}}$and Rho-dependent activation of phospholipase $\mathrm{C}_{\varepsilon}$ by lysophosphatidic acid and thrombin receptors. Molecular Pharmacology, 69, 2068.

92. Satoh, T., Edamatsu, H., \& Kataoka, T. (2007). Phospholipase Ce guanine nucleotide exchange factor activity and activation of Rap1. Methods in Enzymology, 407, 281.

93. Kelley, G. G., Kaproth-Joslin, K. A., Reks, S. E., Smrcka, A. V., \& Wojcikiewicz, R. J. (2006). G-protein-coupled receptor agonists activate endogenous phospholipase $\mathrm{C} \varepsilon$ and phospholipase $\mathrm{C} \beta 3$ in a temporally distinct manner. The Journal of Biological Chemistry, 281, 2639.

94. Oestreich, E. A., Malik, S., Goonasekera, S. A., Blaxall, B. C., Kelley, G. G., Dirksen, R. T., et al. (2009). Epac and phospholipase $\mathrm{C}_{\varepsilon}$ regulate $\mathrm{Ca}^{2+}$ release in the heart by activation of protein kinase $c_{\varepsilon}$ and calcium-calmodulin kinase II. The Journal of Biological Chemistry, 284, 1514.

95. Yujiri, T., Sather, S., Fanger, G. R., \& Johnson, G. L. (1998). Role of MEKK1 in cell survival and activation of JNK and ERK pathways defined by targeted gene disruption. Science, 282, 1911.

96. Lips, D. J., Bueno, O. F., Wilkins, B. J., Purcell, N. H., Kaiser, R. A., Lorenz, J. N., et al. (2004). MEK1-ERK2 signaling pathway protects myocardium from ischemic injury in vivo. Circulation, 109, 1938.

97. Purcell, N. H., Wilkins, B. J., York, A., Saba-El-Leil, M. K., Meloche, S., Robbins, J., et al. (2007). Genetic inhibition of cardiac ERK1/2 promotes stress-induced apoptosis and heart failure but has no effect on hypertrophy in vivo. Proceedings of the National Academy of Sciences of the United States of America, 104, 14074.

98. Inagaki, K., Churchill, E., \& Mochly-Rosen, D. (2006). Epsilon protein kinase $\mathrm{C}$ as a potential therapeutic target for the ischemic heart. Cardiovascular Research, 70, 222.

99. Liu, G. S., Cohen, M. V., Mochly-Rosen, D., \& Downey, J. M. (1999). Protein kinase C- $\varepsilon$ is responsible for the protection of preconditioning in rabbit cardiomyocytes. Journal of Molecular and Cellular Cardiology, 31, 1937.

100. Xuan, Y. T., Guo, Y., Zhu, Y., Wang, O. L., Rokosh, G., Messing, R. O., et al. (2005). Role of the protein kinase C- - -Raf1-MEK-1/2-p44/42 MAPK signaling cascade in the activation of signal transducers and activators of transcription 1 and 3 and induction of cyclooxygenase- 2 after ischemic preconditioning. Circulation, 112, 1971.

101. Zhang, W. H., Lu, F. H., Zhao, Y. J., Wang, L. N., Tian, Y., Pan, Z. W., et al. (2007). Post-conditioning protects rat cardiomyocytes via $\mathrm{PKC} \varepsilon$-mediated calcium-sensing receptors. Biochemical and Biophysical Research Communications, 361, 659.

102. Sivaraman, V., Hausenloy, D. J., Kolvekar, S., Hayward, M., Yap, J., Lawrence, D., et al. (2009). The divergent roles of protein kinase $\mathrm{C} \varepsilon$ and $\delta$ in simulated ischaemia-reperfusion injury in human myocardium. Journal of Molecular and Cellular Cardiology, 46, 758.

103. Wang, H., Oestreich, E. A., Maekawa, N., Bullard, T. A., Vikstrom, K. L., Dirksen, R. T., et al. (2005). Phospholipase Ce modulates $\beta$-adrenergic receptor-dependent cardiac contraction and inhibits cardiac hypertrophy. Circulation Research, 97, 1305.

104. Yoshimura, S., Nakashima, S., Ohguchi, K., Sakai, H., Shinoda, J., Sakai, N., et al. (1996). Differential mRNA expression of phospholipase D (PLD) isozymes during cAMP-induced differentiation in C6 glioma cells. Biochemical and Biophysical Research Communications, 225, 494.

105. Hammond, S. M., Jenco, J. M., Nakashima, S., Cadwallader, K., $\mathrm{Gu}$, Q., Cook, S., et al. (1997). Characterization of two alternately spliced forms of phospholipase D1. Activation of the purified enzymes by phosphatidylinositol 4, 5-bisphosphate, ADP-ribosylation factor, and Rho family monomeric GTPbinding proteins and protein kinase $\mathrm{C}-\alpha$. The Journal of Biological Chemistry, 272, 3860.

106. Redina, O. E., \& Frohman, M. A. (1998). Organization and alternative splicing of the murine phospholipase D2 gene. The Biochemical Journal, 331(Pt 3), 845.

107. Colley, W. C., Sung, T. C., Roll, R., Jenco, J., Hammond, S. M., Altshuller, Y., et al. (1997). Phospholipase D2, a distinct phospholipase D isoform with novel regulatory properties that provokes cytoskeletal reorganization. Current Biology, 7, 191.

108. Bae, C. D., Min, D. S., Fleming, I. N., \& Exton, J. H. (1998). Determination of interaction sites on the small $G$ protein RhoA for phospholipase D. The Journal of Biological Chemistry, 273, 11596.

109. Sung, T. C., Zhang, Y., Morris, A. J., \& Frohman, M. A. (1999). Structural analysis of human phospholipase D1. The Journal of Biological Chemistry, 274, 3659.

110. Xie, Z., Ho, W. T., Spellman, R., Cai, S., \& Exton, J. H. (2002). Mechanisms of regulation of phospholipase D1 and D2 by the heterotrimeric $\mathrm{G}$ proteins $\mathrm{G}_{13}$ and $\mathrm{G}_{\mathrm{q}}$. The Journal of Biological Chemistry, 277, 11979.

111. Du, G., Altshuller, Y. M., Kim, Y., Han, J. M., Ryu, S. H., Morris, A. J., et al. (2000). Dual requirement for rho and protein kinase $\mathrm{C}$ in direct activation of phospholipase D1 through $\mathrm{G}$ protein-coupled receptor signaling. Molecular Biology of the Cell, 11, 4359.

112. Schmidt, M., Rumenapp, U., Bienek, C., Keller, J., von EichelStreiber, C., \& Jakobs, K. H. (1996). Inhibition of receptor signaling to phospholipase D by Clostridium difficile toxin B. Role of Rho proteins. The Journal of Biological Chemistry, 271, 2422.

113. Schmidt, M., Voss, M., Oude Weernink, P. A., Wetzel, J., Amano, M., Kaibuchi, K., et al. (1999). A role for Rho-kinase in Rho-controlled phospholipase D stimulation by the $\mathrm{m} 3$ muscarinic acetylcholine receptor. The Journal of Biological Chemistry, 274, 14648.

114. Yamazaki, M., Zhang, Y., Watanabe, H., Yokozeki, T., Ohno, S., Kaibuchi, K., et al. (1999). Interaction of the small G protein RhoA with the $\mathrm{C}$ terminus of human phospholipase D1. The Journal of Biological Chemistry, 274, 6035.

115. Schmidt, M., Nehls, C., Rumenapp, U., \& Jakobs, K. H. (1996). $\mathrm{m} 3$ Muscarinic receptor-induced and $\mathrm{G}_{\mathrm{i}}$-mediated heterologous potentiation of phospholipase C stimulation: Role of phosphoinositide synthesis. Molecular Pharmacology, 50, 1038.

116. Miyamoto, S., Murphy, A. N., \& Brown, J. H. (2008). Akt mediates mitochondrial protection in cardiomyocytes through phosphorylation of mitochondrial hexokinase-II. Cell Death and Differentiation, 15, 521.

117. Miyamoto, S., Murphy, A. N., \& Brown, J. H. (2009). Akt mediated mitochondrial protection in the heart: metabolic and survival pathways to the rescue. Journal of Bioenergetics and Biomembranes, 41, 169.

118. Lecour, S. (2009). Activation of the protective survivor activating factor enhancement (SAFE) pathway against reperfusion injury: Does it go beyond the RISK pathway? Journal of Molecular and Cellular Cardiology, 47, 32.

119. Lecour, S. (2009). Multiple protective pathways against reperfusion injury: A SAFE path without Aktion? Journal of Molecular and Cellular Cardiology, 46, 607.

120. Taher, M. M., Mahgoub, M. A., \& Abd-Elfattah, A. S. (1998). Redox regulation of signal transduction in vascular smooth muscle cells: thiol oxidizing agents induced phospholipase D. Biochemistry and Molecular Biology International, 46, 619.

121. Natarajan, V., Vepa, S., Verma, R. S., \& Scribner, W. M. (1996). Role of protein tyrosine phosphorylation in $\mathrm{H} 2 \mathrm{O} 2$-induced 
activation of endothelial cell phospholipase D. The American Journal of Physiology, 271, L400.

122. Parinandi, N. L., Scribner, W. M., Vepa, S., Shi, S., \& Natarajan, V. (1999). Phospholipase D activation in endothelial cells is redox sensitive. Antioxidants Redox Signaling, 1, 193.

123. Banno, Y., Wang, S., Ito, Y., Izumi, T., Nakashima, S., Shimizu, T., et al. (2001). Involvement of ERK and p38 MAP kinase in oxidative stress-induced phospholipase D activation in PC12 cells. NeuroReport, 12, 2271.

124. Kim, J. H., Lee, S., Park, J. B., Lee, S. D., Kim, J. H., Ha, S. H., et al. (2003). Hydrogen peroxide induces association between glyceraldehyde 3-phosphate dehydrogenase and phospholipase D2 to facilitate phospholipase D2 activation in PC12 cells. Journal of Neurochemistry, 85, 1228.

125. Dai, J., Meij, J. T., Padua, R., \& Panagia, V. (1992). Depression of cardiac sarcolemmal phospholipase D activity by oxidant-induced thiol modification. Circulation Research, 71,970 .

126. Dai, J., Meij, J. T., Dhalla, V., \& Panagia, V. (1995). Involvement of thiol groups in the impairment of cardiac sarcoplasmic reticular phospholipase D activity by oxidants. Journal of Lipid Mediators and Cell Signalling, 11, 107.

127. Asemu, G., Dent, M. R., Singal, T., Dhalla, N. S., \& Tappia, P. S. (2005). Differential changes in phospholipase D and phosphatidate phosphohydrolase activities in ischemia-reperfusion of rat heart. Archives of Biochemistry and Biophysics, 436, 136.

128. Bruhl, A., Faldum, A., \& Loffelholz, K. (2003). Degradation of phosphatidylethanol counteracts the apparent phospholipase Dmediated formation in heart and other organs. Biochimica et Biophysica Acta, 1633, 84.

129. Kurz, T., Kemken, D., Mier, K., Weber, I., \& Richardt, G. (2004). Human cardiac phospholipase D activity is tightly controlled by phosphatidylinositol 4, 5-bisphosphate. Journal of Molecular and Cellular Cardiology, 36, 225.

130. Cohen, M. V., Liu, Y., Liu, G. S., Wang, P., Weinbrenner, C., Cordis, G. A., et al. (1996). Phospholipase D plays a role in ischemic preconditioning in rabbit heart. Circulation, 94, 1713.

131. Tosaki, A., Maulik, N., Cordis, G., Trifan, O. C., Popescu, L. M., \& Das, D. K. (1997). Ischemic preconditioning triggers phospholipase D signaling in rat heart. The American Journal of Physiology, 273, H1860.

132. Mozzicato, S., Joshi, B. V., Jacobson, K. A., \& Liang, B. T. (2004). Role of direct RhoA-phospholipase D1 interaction in mediating adenosine-induced protection from cardiac ischemia. The FASEB Journal, 18, 406.

133. Braz, J. C., Gregory, K., Pathak, A., Zhao, W., Sahin, B., Klevitsky, R., et al. (2004). PKC- $\alpha$ regulates cardiac contractility and propensity toward heart failure. Natural Medicines, 10, 248.

134. Liu, Q., Chen, X., MacDonnell, S. M., Kranias, E. G., Lorenz, J. N., Leitges, M., et al. (2009). Protein kinase $C_{\alpha}$, but not PKC $\beta$ or $\mathrm{PKC} \gamma$, regulates contractility and heart failure susceptibility: Implications for ruboxistaurin as a novel therapeutic approach. Circulation Research, 105, 194.

135. Saurin, A. T., Pennington, D. J., Raat, N. J., Latchman, D. S., Owen, M. J., \& Marber, M. S. (2002). Targeted disruption of the protein kinase $\mathrm{C} \varepsilon$ gene abolishes the infarct size reduction that follows ischaemic preconditioning of isolated buffer-perfused mouse hearts. Cardiovascular Research, 55, 672.

136. Zatta, A. J., Kin, H., Lee, G., Wang, N., Jiang, R., Lust, R., et al. (2006). Infarct-sparing effect of myocardial postconditioning is dependent on protein kinase $\mathrm{C}$ signalling. Cardiovascular Research, 70, 315.

137. Mayr, M., Metzler, B., Chung, Y. L., McGregor, E., Mayr, U., Troy, H., et al. (2004). Ischemic preconditioning exaggerates cardiac damage in PKC- $\delta$ null mice. American Journal of Physiology. Heart and Circulatory Physiology, 287, H946.
138. Churchill, E. N., \& Szweda, L. I. (2005). Translocation of $\delta P K C$ to mitochondria during cardiac reperfusion enhances superoxide anion production and induces loss in mitochondrial function. Archives of Biochemistry and Biophysics, 439, 194.

139. Churchill, E. N., Murriel, C. L., Chen, C. H., Mochly-Rosen, D., \& Szweda, L. I. (2005). Reperfusion-induced translocation of $\delta \mathrm{PKC}$ to cardiac mitochondria prevents pyruvate dehydrogenase reactivation. Circulation Research, 97, 78.

140. Inagaki, K., Chen, L., Ikeno, F., Lee, F. H., Imahashi, K., Bouley, D. M., et al. (2003). Inhibition of $\delta$-protein kinase $C$ protects against reperfusion injury of the ischemic heart in vivo. Circulation, 108, 2304.

141. Murriel, C. L., Churchill, E., Inagaki, K., Szweda, L. I., \& Mochly-Rosen, D. (2004). Protein kinase C $\delta$ activation induces apoptosis in response to cardiac ischemia and reperfusion damage: A mechanism involving $\mathrm{BAD}$ and the mitochondria. The Journal of Biological Chemistry, 279, 47985.

142. Murriel, C. L., \& Mochly-Rosen, D. (2003). Opposing roles of $\delta$ and $\varepsilon \mathrm{PKC}$ in cardiac ischemia and reperfusion: targeting the apoptotic machinery. Archives of Biochemistry and Biophysics, 420, 246.

143. Chen, L., Hahn, H., Wu, G., Chen, C. H., Liron, T., Schechtman, D., et al. (2001). Opposing cardioprotective actions and parallel hypertrophic effects of $\delta \mathrm{PKC}$ and $\varepsilon \mathrm{PKC}$. Proceedings of the National Academy of Sciences of the United States of America, 98, 11114

144. Inagaki, K., Hahn, H. S., Dorn, G. W., \& Mochly-Rosen, D. (2003). Additive protection of the ischemic heart ex vivo by combined treatment with $\delta$-protein kinase $\mathrm{C}$ inhibitor and $\varepsilon$ protein kinase C activator. Circulation, 108, 869.

145. Haworth, R. S., Roberts, N. A., Cuello, F., \& Avkiran, M. (2007). Regulation of protein kinase D activity in adult myocardium: novel counter-regulatory roles for protein kinase $\mathrm{C} \varepsilon$ and protein kinase A. Journal of Molecular and Cellular Cardiology, 43, 686.

146. Rey, O., Reeve, J. R., Jr., Zhukova, E., Sinnett-Smith, J., \& Rozengurt, E. (2004). G protein-coupled receptor-mediated phosphorylation of the activation loop of protein kinase D: Dependence on plasma membrane translocation and protein kinase C $\varepsilon$. The Journal of Biological Chemistry, 279, 34361.

147. Brandlin, I., Eiseler, T., Salowsky, R., \& Johannes, F. J. (2002). Protein kinase $\mathrm{C} \mu$ regulation of the $\mathrm{JNK}$ pathway is triggered via phosphoinositide-dependent kinase 1 and protein kinase $\mathrm{C} \varepsilon$. The Journal of Biological Chemistry, 277, 45451.

148. Tan, M., Xu, X., Ohba, M., Ogawa, W., \& Cui, M. Z. (2003). Thrombin rapidly induces protein kinase $\mathrm{D}$ phosphorylation, and protein kinase $\mathrm{C} \delta$ mediates the activation. The Journal of Biological Chemistry, 278, 2824.

149. Haworth, R. S., Cuello, F., Herron, T. J., Franzen, G., Kentish, J. C., Gautel, M., et al. (2004). Protein kinase D is a novel mediator of cardiac troponin I phosphorylation and regulates myofilament function. Circulation Research, 95, 1091.

150. Cuello, F., Bardswell, S. C., Haworth, R. S., Yin, X., Lutz, S., Wieland, T., et al. (2007). Protein kinase D selectively targets cardiac troponin I and regulates myofilament $\mathrm{Ca}^{2+}$ sensitivity in ventricular myocytes. Circulation Research, 100, 864.

151. Huynh, Q. K., \& McKinsey, T. A. (2006). Protein kinase D directly phosphorylates histone deacetylase 5 via a random sequential kinetic mechanism. Archives of Biochemistry and Biophysics, 450, 141.

152. Vega, R. B., Harrison, B. C., Meadows, E., Roberts, C. R., Papst, P. J., Olson, E. N., et al. (2004). Protein kinases C and D mediate agonistdependent cardiac hypertrophy through nuclear export of histone deacetylase 5. Molecular and Cellular Biology, 24, 8374.

153. Dequiedt, F., Van, L. J., Lecomte, E., Van, D., Seufferlein, V. T., Vandenheede, J. R., et al. (2005). Phosphorylation of histone 
deacetylase 7 by protein kinase D mediates T cell receptorinduced Nur77 expression and apoptosis. The Journal of Experimental Medicine, 201, 793.

154. Storz, P., \& Toker, A. (2003). Protein kinase D mediates a stressinduced NF-kappaB activation and survival pathway. The EMBO Journal, 22, 109.

155. Storz, P., Doppler, H., \& Toker, A. (2005). Protein kinase D mediates mitochondrion-to-nucleus signaling and detoxification from mitochondrial reactive oxygen species. Molecular and Cellular Biology, 25, 8520 .

156. Avkiran, M., Rowland, A. J., Cuello, F., \& Haworth, R. S. (2008). Protein kinase $d$ in the cardiovascular system: Emerging roles in health and disease. Circulation Research, 102, 157.

157. Yuan, J., Slice, L. W., \& Rozengurt, E. (2001). Activation of protein kinase $\mathrm{D}$ by signaling through Rho and the $\alpha$ subunit of the heterotrimeric $\mathrm{G}$ protein $\mathrm{G}_{13}$. The Journal of Biological Chemistry, 276, 38619.

158. Cowell, C. F., Yan, I. K., Eiseler, T., Leightner, A. C., Doppler, H., \& Storz, P. (2009). Loss of cell-cell contacts induces NFkappaB via RhoA-mediated activation of protein kinase D1. Journal of Cellular Biochemistry, 106, 714.

159. Song, J., Li, J., Lulla, A., Evers, B. M., \& Chung, D. H. (2006). Protein kinase D protects against oxidative stress-induced intestinal epithelial cell injury via Rho/ROK/PKC- $\delta$ pathway activation. American Journal of Physiology. Cell Physiology, 290, C1469.

160. Laudanna, C., Campbell, J. J., \& Butcher, E. C. (1996). Role of Rho in chemoattractant-activated leukocyte adhesion through integrins. Science, 271, 981.

161. Kaibuchi, K., Kuroda, S., \& Amano, M. (1999). Regulation of the cytoskeleton and cell adhesion by the Rho family GTPases in mammalian cells. Annual Review of Biochemistry, 68, 459.

162. Seasholtz, T. M., Majumdar, M., Kaplan, D. D., \& Brown, J. H. (1999). Rho and Rho kinase mediate thrombin-stimulated vascular smooth muscle cell DNA synthesis and migration. Circulation Research, 84, 1186.

163. Schmitz, A. A., Govek, E. E., Bottner, B., \& Van Aelst, L. (2000). Rho GTPases: Signaling, migration, and invasion. Experimental Cell Research, 261, 1.

164. Ridley, A. J. (2001). Rho GTPases and cell migration. Journal of Cell Science, 114, 2713.

165. Etienne-Manneville, S., \& Hall, A. (2002). Rho GTPases in cell biology. Nature, 420, 629 .

166. Sahai, E., \& Marshall, C. (2002). RHO-GTPases and cancer. Nature Reviews, 2, 133.

167. Raftopoulou, M., \& Hall, A. (2004). Cell migration: Rho GTPases lead the way. Developmental Biology, 265, 23.

168. Jaffe, A. B., \& Hall, A. (2005). Rho GTPases: Biochemistry and biology. Annual Review of Cell and Developmental Biology, 21, 247.

169. Yamaguchi, H., \& Condeelis, J. (2007). Regulation of the actin cytoskeleton in cancer cell migration and invasion. Biochimica et Biophysica Acta, 1773, 642.

170. Hill, C. S., Wynne, J., \& Treisman, R. (1995). The Rho family GTPases RhoA, Rac1, and $\mathrm{CDC} 42 \mathrm{Hs}$ regulate transcriptional activation by SRF. Cell, 81,1159 .

171. Gauthier-Rouviere, C., Cavadore, J. C., Blanchard, J. M., Lamb, N. J., \& Fernandez, A. (1991). p67SRF is a constitutive nuclear protein implicated in the modulation of genes required throughout the G1 period. Cell Regulation, 2, 575.

172. Hill, C. S., \& Treisman, R. (1995). Transcriptional regulation by extracellular signals: mechanisms and specificity. Cell, 80, 199.

173. Bence, K., Ma, W., Kozasa, T., \& Huang, X.-Y. (1997). Direct stimulation of Bruton's tyrosine kinase by $\mathrm{G}_{\mathrm{q}}$-protein $\alpha$-subunit. Nature, 389, 296.

174. Fromm, C., Coso, O. A., Montaner, S., Xu, N., \& Gutkind, J. S. (1997). The small GTP-binding protein Rho links G protein- coupled receptors and $\mathrm{G} \alpha_{12}$ to the serum response element and to cellular transformation. Proceedings of the National Academy of Sciences of the United States of America, 91, 10098.

175. Shore, P., \& Sharrocks, A. D. (1995). The MADS-box family of transcription factors. European Journal of Biochemistry, $229,1$.

176. Treisman, R. (1994). Ternary complex factors: Growth factor regulated transcriptional activators. Current Opinion in Genetics \& Development, 4, 96

177. Cen, B., Selvaraj, A., Burgess, R. C., Hitzler, J. K., Ma, Z., Morris, S. W., et al. (2003). Megakaryoblastic leukemia 1, a potent transcriptional coactivator for serum response factor (SRF), is required for serum induction of SRF target genes. Molecular and Cellular Biology, 23, 6597.

178. Cen, B., Selvaraj, A., \& Prywes, R. (2004). Myocardin/MKL family of SRF coactivators: Key regulators of immediate early and muscle specific gene expression. Journal of Cellular Biochemistry, 93, 74.

179. Posern, G., \& Treisman, R. (2006). Actin' together: Serum response factor, its cofactors and the link to signal transduction. Trends in Cell Biology, 16, 588.

180. Johansen, F. E., \& Prywes, R. (1995). Serum response factor: Transcriptional regulation of genes induced by growth factors and differentiation. Biochimica et Biophysica Acta, 1242, 1.

181. Ueyama, T., Sakoda, T., Kawashima, S., Hiraoka, E., Hirata, K., Akita, H., et al. (1997). Activated RhoA stimulates c-fos gene expression in myocardial cells. Circulation Research, 81, 672.

182. Morissette, M. R., Sah, V. P., Glembotski, C. C., \& Brown, J. H. (2000). The Rho effector, PKN, regulates ANF gene transcription in cardiomyocutes through a serum response element. The American Journal of Physiology, 278, H1769.

183. Wang, D. Z., Li, S., Hockemeyer, D., Sutherland, L., Wang, Z., Schratt, G., et al. (2002). Potentiation of serum response factor activity by a family of myocardin-related transcription factors. Proceedings of the National Academy of Sciences of the United States of America, 99, 14855.

184. Parmacek, M. S. (2007). Myocardin-related transcription factors: Critical coactivators regulating cardiovascular development and adaptation. Circulation Research, 100, 633.

185. Sotiropoulos, A., Gineitis, D., Copeland, J., \& Treisman, R. (1999). Signal-regulated activation of serum response factor is mediated by changes in actin dynamics. Cell, 98, 159.

186. Wang, D., Chang, P. S., Wang, Z., Sutherland, L., Richardson, J. A., Small, E., et al. (2001). Activation of cardiac gene expression by myocardin, a transcriptional cofactor for serum response factor. Cell, 105, 851.

187. Wang, Z., Wang, D. Z., Pipes, G. C., \& Olson, E. N. (2003). Myocardin is a master regulator of smooth muscle gene expression. Proceedings of the National Academy of Sciences of the United States of America, 100, 7129.

188. Miralles, F., Posern, G., Zaromytidou, A. I., \& Treisman, R. (2003). Actin dynamics control SRF activity by regulation of its coactivator MAL. Cell, 113, 329.

189. Lockman, K., Hinson, J. S., Medlin, M. D., Morris, D., Taylor, J. M., \& Mack, C. P. (2004). Sphingosine 1-phosphate stimulates smooth muscle cell differentiation and proliferation by activating separate serum response factor co-factors. The Journal of Biological Chemistry, 279, 42422.

190. Geneste, O., Copeland, J. W., \& Treisman, R. (2002). LIM kinase and Diaphanous cooperate to regulate serum response factor and actin dynamics. The Journal of Cell Biology, 157, 831.

191. Muehlich, S., Wang, R., Lee, S. M., Lewis, T. C., Dai, C., \& Prywes, R. (2008). Serum-induced phosphorylation of the serum response factor coactivator MKL1 by the extracellular signalregulated kinase $1 / 2$ pathway inhibits its nuclear localization. Molecular and Cellular Biology, 28, 6302. 
192. Vartiainen, M. K., Guettler, S., Larijani, B., \& Treisman, R. (2007). Nuclear actin regulates dynamic subcellular localization and activity of the SRF cofactor MAL. Science, 316, 1749.

193. Arsenian, S., Weinhold, B., Oelgeschlager, M., Ruther, U., \& Nordheim, A. (1998). Serum response factor is essential for mesoderm formation during mouse embryogenesis. The EMBO Journal, 17, 6289.

194. Du, K. L., Chen, M., Li, J., Lepore, J. J., Mericko, P., \& Parmacek, M. S. (2004). Megakaryoblastic leukemia factor-1 transduces cytoskeletal signals and induces smooth muscle cell differentiation from undifferentiated embryonic stem cells. The Journal of Biological Chemistry, 279, 17578.

195. Selvaraj, A., \& Prywes, R. (2004). Expression profiling of serum inducible genes identifies a subset of SRF target genes that are MKL dependent. BMC Molecular Biology, 5, 13.

196. Perbal, B. (2004). CCN proteins: multifunctional signalling regulators. Lancet, 363, 62.

197. Leask, A., \& Abraham, D. J. (2006). All in the CCN family: essential matricellular signaling modulators emerge from the bunker. Journal of Cell Science, 119, 4803.

198. Chen, C. C., \& Lau, L. F. (2008). Functions and mechanisms of action of CCN matricellular proteins. International Journal of Biochemistry \& Cell Biology.

199. Brigstock, D. R. (1999). The connective tissue growth factor/ cysteine-rich 61/nephroblastoma overexpressed (CCN) family. Endocrine Reviews, 20, 189.

200. Yang, G. P., \& Lau, L. F. (1991). Cyr61, product of a growth factor-inducible immediate early gene, is associated with the extracellular matrix and the cell surface. Cell Growth \& Differentiation, 2, 351.

201. O'Brien, T. P., Yang, G. P., Sanders, L., \& Lau, L. F. (1990). Expression of cyr61, a growth factor-inducible immediate-early gene. Molecular and Cellular Biology, 10, 3569.

202. Kireeva, M. L., Mo, F. E., Yang, G. P., \& Lau, L. F. (1996). Cyr61, a product of a growth factor-inducible immediate-early gene, promotes cell proliferation, migration, and adhesion. Molecular and Cellular Biology, 16, 1326.

203. Chen, Y., \& Du, X. Y. (2007). Functional properties and intracellular signaling of CCN1/Cyr61. Journal of Cellular Biochemistry, 100, 1337.

204. Walsh, C. T., Stupack, D., \& Brown, J. H. (2008). G proteincoupled receptors go extracellular: RhoA integrates the integrins. Molecular Interventions, 8, 165.
205. Tamura, I., Rosenbloom, J., Macarak, E., \& Chaqour, B. (2001). Regulation of Cyr61 gene expression by mechanical stretch through multiple signaling pathways. American Journal of Physiology. Cell Physiology, 281, C1524.

206. Chaqour, B., \& Goppelt-Struebe, M. (2006). Mechanical regulation of the $\mathrm{Cyr} 61 / \mathrm{CCN} 1$ and $\mathrm{CTGF} / \mathrm{CCN} 2$ proteins. The FEBS Journal, 273, 3639

207. Yang, R., Amir, J., Liu, H., \& Chaqour, B. (2008). Mechanical strain activates a program of genes functionally involved in paracrine signaling of angiogenesis. Physiological Genomics, 36, 1.

208. Hanna, M., Liu, H., Amir, J., Sun, Y., Morris, S. W., Siddiqui, M., et al. (2009). Mechanical regulation of the proangiogenic factor CCN1/CYR61 gene requires the combined activities of the myocardin-related transcription factor (MRTF)-A and CREB binding protein (CBP) histone acetyl transferase. The Journal of Biological Chemistry, 284, 23125.

209. Gabrielsen, A., Lawler, P. R., Yongzhong, W., Steinbruchel, D., Blagoja, D., Paulsson-Berne, G., et al. (2007). Gene expression signals involved in ischemic injury, extracellular matrix composition and fibrosis defined by global mRNA profiling of the human left ventricular myocardium. Journal of Molecular and Cellular Cardiology, 42, 870.

210. Wittchen, F., Suckau, L., Witt, H., Skurk, C., Lassner, D., Fechner, H., et al. (2007). Genomic expression profiling of human inflammatory cardiomyopathy (DCMi) suggests novel therapeutic targets. Journal of Molecular Medicine, 85, 257.

211. Hilfiker-Kleiner, D., Kaminski, K., Kaminska, A., Fuchs, M., Klein, G., Podewski, E., et al. (2004). Regulation of proangiogenic factor $\mathrm{CCN} 1$ in cardiac muscle: impact of ischemia, pressure overload, and neurohumoral activation. Circulation, $109,2227$.

212. Han, J. S., Macarak, E., Rosenbloom, J., Chung, K. C., \& Chaqour, B. (2003). Regulation of Cyr61/CCN1 gene expression through RhoA GTPase and p38MAPK signaling pathways. European Journal of Biochemistry, 270, 3408.

213. Young, N., \& Van, B., Jr. (2007). Roles of sphingosine-1phosphate (S1P) receptors in malignant behavior of glioma cells. Differential effects of S1P2 on cell migration and invasiveness. Experimental Cell Research, 313, 1615.

214. Yoshida, Y., Togi, K., Matsumae, H., Nakashima, Y., Kojima, Y., Yamamoto, H., et al. (2007). CCN1 protects cardiac myocytes from oxidative stress via $\beta 1$ integrin-Akt pathway. Biochemical and Biophysical Research Communications, 355, 611. 